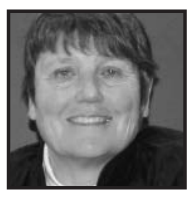

\title{
Narrative Understandings of Lives Lived in and out of Schools
}

\author{
D. Jean Clandinin, University of Alberta
}

\section{ABSTRACT}

Drawing on a narrative inquiry into the experiences of 19 youth who left school without graduating, I raise questions about stories of school, the institutional narrative of schooling. Through inquiring into the youths' stories, we identified six resonant threads that spoke to the complexities of their lives. Their lives awakened us to what might be possible if we engaged with their stories as a way to open up or disrupt current stories of schools to allow for the reimagining of schools. Through attending to youths' stories we might make the experience of youth, in their life contexts, the starting point not only for education but also for schooling.

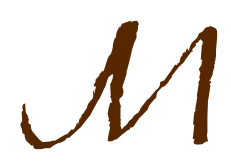

y scholarly and personal interests intertwine in my research in understanding lives narratively, as unfolding, enfolding, nested compositions (Clandinin \& Connelly, 2000; Clandinin et al., 2006). For many years now, following John Dewey's (1938) ideas on education as experience, I have worked with others to attend to lives in the making, lives in motion. For the most part I have come alongside teachers, student teachers, children, parents and others as their lives met in schools and, while I may have spent time with them in other places such as homes and other social places, we began our inquiries together in schools. By this I draw attention to how schools were the common ground of meeting and we moved in and out of schools, telling, in our words, actions, and bodies, stories of our knowing and of our identities (Clandinin \& Connelly, 1995; Connelly \& Clandinin, 1996). 
In a recent project, alongside a group of other researchers (Clandinin et al., 2010), we became intrigued by the life-composing of youth who had left schools. We came alongside young people who had left school prior to high school completion so that we might learn more about their storied experiences, recognizing that their lives in school were only part of their much larger life compositions. We were interested in learning of their lives and, perhaps through learning about their lives, we wanted to learn more about our lives as educators and more about schools. Our overall intentions were, in part, to learn about what we call stories of school and about how we might begin to shift those stories.

In our narrative inquiry we, a group of 11 researchers, came alongside 19 youth between the ages of 18 and 21 who left school before graduating and who had been out of school for more than a year. We selected youth whose life experiences were diverse. They lived in rural, urban, and suburban places. We included males and females; youth of diverse heritages; youth of different family constellations; youth of different socioeconomic groupings, and so on. We did not come alongside teachers or meet these youth in schools. We met them in the midst of their complex, ongoing lives, lives that had not yet, at least, included high school graduation. We engaged with each youth in a series of conversations shaped by our overall research puzzles around how their lives shaped their leaving of school and how leaving school shaped their lives.

At first, we composed narrative accounts of our unique experiences with the youth we had engaged in the conversations. We then looked across the 19 individual narrative accounts to inquire into resonant threads or patterns that we could discern. We did so in order to offer a deeper and broader awareness of the experiences of early school leavers with an overall intention to open up new wonders and questions about early school leaving and, in part, to help us learn more about schools and how to shape them in ways that might be more responsive to the life-composing of all youth.

We identified six resonant threads: conversational spaces; relationships; identities; complexities over time; responsibilities; cultural, social and institutional narratives. We say much more about these threads in other places (Clandinin et al., 2010), but for now I briefly summarize each thread.

1. The importance of conversational spaces for telling and retelling life stories became evident in the research conversations. We wondered if such conversation spaces along the way might have helped some of the youths to feel less 
alone in composing their lives within complex institutional, social, cultural, linguistic and familial narratives.

2. The importance of relationships to the youths was multidimensional and became visible throughout our research. The participants' relationships with family, peers, programs of study, and teachers, as well as the interruption of relationships through disruptions and transitions, exemplified the significance of relationship-connection and association-when we thought about early school leaving.

3. The youths were composing their identities on elementary, junior high, and senior high school landscapes as well as on complex home and community landscapes. While they saw themselves composing who they were and were becoming, they did not tell their stories as dropouts. A number of them actively resisted the label, telling their stories around plotlines of "not in school, for now." Their forward-looking stories included school.

4. Looking across multiple stories, we were struck by the complexity of stories lived when whole lives were considered. When early school leaving was seen as a complex set of storied events composed over time, the notion of a discrete decision or factor in dropping out of school became problematic. Complexity in composing lives over time became evident in the lives of the youths who left school early.

5. Relational responsibility threads were evident in many of the narrative accounts. Many of the youths were composing lives in which they struggled to balance conflicting responsibilities. At times it seemed as though they were trying to compose lives that allowed them to shift between, and across, multiple responsibilities. The institutional, familial, and cultural narratives in which they were embedded shaped their experiences.

6. All stories are embedded within social, cultural, institutional, and family narratives that shape, and are shaped by, individuals' stories to live by (Connelly \& Clandinin, 1999). As we attended to the cultural, social, familial, linguistic and institutional narratives within which the youths composed their lives, we noted competing plotlines that shaped their stories to live by. The youths' stories spoke of, and to, contradictions between cultural narratives, familial narratives and stories of school. Caught sometimes in these contradictions, youth were humiliated or embarrassed in front of other students. Within the institutional landscape, 
composing an identity seemed to be more challenging than passively accepting one.

These six resonant threads spoke to the complexities of the lives the youth were composing. Their lives awakened us to what might be possible if we engaged with their stories as a way to open up or disrupt current stories of schools to allow for the reimagining of schools.

As we ended our narrative inquiry with the youth, we questioned the discourses around stories of youth who left school early with its embedded assumptions around school leaving. We questioned the discourses of risk factors, resiliency and the focus on school leaving as a singular event, rather than a process over time. We realize we do need to change the discourse, research, policies and practices around youth who leave school early.

We also awakened to, and began to question, some of our assumptions: Is school a good place for everyone? Is it a good place at all times? Is it the only place to be successful? There were moments in the youths' stories where they experienced a good teacher, a good friend, a good principal. Yet there were also times when school was a difficult place, or when their lives outside of school were too complex to allow spaces for school.

We wonder how we can engage these stories and learn to attend more to the voices of youth in our attempts to begin to change the stories of school. We realized that by staying quiet and listening, the stories of youth, those who stay and those who leave, might begin to offer possibilities for shaping the kinds of places schools can become. Might a stance of mindfulness on the part of all who interact with youth in and out of school, enlarge the possibilities for encouraging and supporting youths to compose their lives in ways that are meaningful to them?

We wonder how the youths' dreams about who they might become can be supported. What part do we play in this-we, as members of the larger educational community, as teachers, nurses, parents, friends, administrators, social workers and others? Do we live on the margins of who they are or do we enter the personal and intimate relational spaces, spaces that call forth engagement and relational responsibilities? As a society, how do we honour, support and encourage diverse identities?

Hearing the youths' complicated life stories composed around multiple changes, we began to question the singular notion of transition from school to work. 
Where are the stories to help youth negotiate these in-between spaces as they moved in and out of school, in and out of work?

In the youths' stories, we saw schools as narrowly defined places for students to gain prescribed knowledge, skills and attitudes. In their stories, we heard them speak of leaving their multiplicity, the wholeness of who they are and the stories they are in the midst of living, at the door of the school. What might happen if school was understood as a space where learning and living were intertwined? Attending to schooling in this way would allow us to pay attention to the particularities of each youth's unfolding life. Thinking in this way we begin to see the importance of schools as sites of collaboration-sites where students interact with peers, with parents, with families, with teachers and principals, with counsellors and therapists, with nurses and speech language pathologists and other service providers.

The youths' stories call us to, as Dewey (1938) wrote so long ago, make the experience of youth in their life contexts the starting point not only for education but also for schooling. Could we begin to reimagine schooling as well as education as places where,

we are interested in openings, in unexplored possibilities, not in the predictable or the quantifiable, not in what is thought of as social control. For us, education signifies an initiation into new ways of seeing, hearing, feeling, moving. It signifies the nurture of a special kind of reflectiveness and expressiveness, a reaching out for meaning, a learning to learn. (Greene, 2001, p. 7)

Can we shift the stories of school in ways that might move us closer to education?

\section{References}

Clandinin, D. J., \& Connelly, F. M. (1995). Teachers' professional knowledge landscapes. New York: Teachers College Press.

Clandinin, D. J., \& Connelly, F. M. (2000). Narrative inquiry: Experience and story in qualitative research. San Francisco: Jossey-Bass.

Clandinin, D. J., Huber, J., Huber, M., Murphy, M. S., Murray-Orr, A., Pearce, M., et al. (2006). Composing diverse identities: Narrative inquiries into the interwoven lives of children and teachers. London: Routledge.

Clandinin, D. J., Steeves, P., Li, Y., Mickelson, J. R., Buck, G., Pearce, M., et al. (2010). Composing lives: A narrative account into the experiences of youth who left school early. Retrieved April 12, 2010, from http://www.uofaweb.ualberta.ca/elemen taryed/CRTED.cfm. 
Connelly, F. M., \& Clandinin, D. J. (1996). Teachers' professional knowledge landscapes: Teacher stories-stories of teachersschool stories-stories of school. Educational Researcher, 25(3), 24-30.

Connelly, F. M., \& Clandinin, D. J. (1999). Shaping a professional identity: Stories of educational practice. New York: Teachers College Press.
Dewey, J. (1938). Experience and education. New York: Collier.

Greene, M. (2001). Variations on a blue guitar: The Lincoln Center Institute lectures on aesthetic education. New York: Teachers College Press.

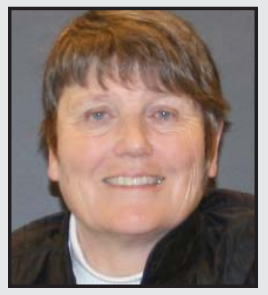

D. Jean Clandinin is Professor and Director of the Centre for Research for Teacher Education and Development at the University of Alberta. She is a former teacher, counsellor, and psychologist. She is the coauthor with F. Michael Connelly of four books and many chapters and articles. Their most recent book, Narrative Inquiry: Experience and Story in Qualitative Research, was published in 2000. In 2001 Jean received the J. Gordin Kaplan Award for Excellence in Research at the University of Alberta and in 2003 she received a Killam Annual Professorship. Jean has recently edited the Handbook of Narrative Inquiry: Mapping a Methodology (Sage, 2007).

\section{LINKTO:}

www.uofaweb.ualberta.ca/elementaryed/CRTED.cfm 